\title{
Determinants of Wheat Crop Production Row Planting Technology Adoption in Duna Woreda, Hadiya Zone, Ethiopia
}

\author{
Negese Tamirat Jemal Abafita Endeg Tekalegn \\ Department of Economics, Jimma University, Jimma, Ethiopia
}

\begin{abstract}
The study was conducted in Duna district, Hadiya Zone, South National Regional State (SNRS). Four wheat producing kebeles among the 23 wheat producing kebeles were selected and a total of 187 selected households were interviewed to generate primary data. Descriptive statistics and binary logit were employed to determine factors that influence the adoption behavior row planting wheat crop production technology of farmers. A sum of ten independent variables for the binary logit model was used, out of which seven variables were found to significantly influence the adoption of row planting of wheat crop production technology. These are: age of the household head, education of household head, family size of household head, size of cultivated land, livestock holding, and use of credit and extension services. The study recommends that any effort in promoting row planting wheat crop production technology should consider the social, economic, institutional and psychological characteristics for better adoption of row planting wheat crop production technology.
\end{abstract}

Keywords: Adoption, Production, Wheat, Row Planting Technology, Binary Logit Model.

DOI: $10.7176 / \mathrm{JBAH} / 9-17-04$

Publication date:September $30^{\text {th }} 2019$

\section{Background of the Study}

Agricultural technology is among the most impactful area of modern technology; play a key role in enhancing agricultural yield, poverty reduction and in improving national food security. It creates spillover effects to the remaining sectors (World Bank, 2014). However, production and productivity of the agricultural sector is low in developing countries due to low technological adoption and techniques among others (Abraham et al., 2014). As a result, food insecurity and poverty are prevalent in developing countries (Alemitu, 2011). The situation in Ethiopia is not any different. Problem such as low technology adoption, low use of recommended farm inputs, broadcast farming and rain-fall are the prime bottlenecks behind the poor performance of the sector (Lulit et al., 2012). Adoption of row planting technology refers to the decision to use a modern technology by a farmer. Livelihood for majority of the population in developing countries from agricultural yield and a modern technology, which creates important opportunities to enhance yield and productivity (Feder et al., 1985).

Ethiopia is an agrarian country where more than $80 \%$ of the total population depends on agriculture. It is basis for the country's food security and the livelihoods of nearly $85 \%$ of its people. It holds about $50 \%$ of the Gross Domestic Product (GDP), $90 \%$ of the total export revenue, $85 \%$ employment of the country's labor force and accounts $70 \%$ of raw materials requirement of the country's industries (MoFED, 2012), but also the engine for the country's Agriculture Development Led Industrialization (ADLI) strategy for many years (ATA, 2013).

Ethiopia is the second-largest wheat producer in SSA next to South Africa (FAO, 2014). It covered about $17 \%$ of the total cereal crop production land area with a mean national product of $21.10 \mathrm{q} / \mathrm{ha}$. Which is the lowest yield compared to the world mean yield of $40 \mathrm{q} / \mathrm{ha}$ (FAO, 2009). This is due to high rain-fed, subsistence oriented, low production system, broadcast farming practices, and decreased soil fertility, unreliable climatic conditions, poor infrastructure, environmental degradation and land scarcity. Country with low production meet the high demand implies that the country remains net importer despite its good potential for wheat yield (Rashid, 2010). Research conducted on row planting of wheat crop production technology a total over 400,000 farm households in four regions: Amhara, Oromia, SNNPR, and Tigray in 200 kebeles. Their studies showed that introduction of row planting wheat crop production technology crucial in enhancing agricultural yield, poverty reduction and in improving national food security. Farmers were convenced on recommended $50 \mathrm{~kg}$ of wheat per hectare who have got impressive yield (a deviation of $75 \%$ to $80 \%$ per hectare) (Sarah, 2014). Therefore, this study was designed to assess the determinants of an adoption of row planting of wheat crop production technology.

Consequently, adoption of improved agricultural technologies such as row planting and transplanting could be quite beneficial in terms of enhancing the productivity and yield levels. Such planting technologies allow for reduced seed rate along with increased space between seedlings, which in turn have been shown to achieve important production increments over traditional broadcasting sowing. More importantly, the technologies allow for better weeding, decreased competition between seedlings, and better branching out and nutrient uptake of the plants (Astatke et al., 2002; Chauhan et al., 2014).

Several adoption research findings have pointed to the fact that the adoption of new row panting agricultural technology could lead to significant enhance in agricultural production in Africa and stimulate the transition from low production subsistence agriculture to a high production agro-industrial economy. Tsegaye and Bekele (2012) 
identifies the main determinants of adoption of improved wheat technologies at farm level. This study uses probit regression model to estimate factors affecting adoption of improved wheat technologies. The result that identified were: age, education, farm experience, off-farm activities, access to credit, extension contact, wheat seed varieties with recommended planting space and livestock holding were significant to affect adoption of improved wheat technologies.

Tolesa et al. (2014) made a research entitled of adoption of row planting of wheat crop production technology by farm household in Arsi Zone of Ethiopia using logit model as total over 133 farmers who found that educational level, access to pesticides, household size, access to improved seed are the factor that significantly affect adoption decision of row planting of wheat crop production of small farm households in the Arsi Zone of Ethiopia. The study emphasized by (Mamudu et al., 2012) showed that Adoption of new agricultural technology; such as row planting technology by farmers in Ghana using logit model as total over 300 farmers who found that plot size, expected returns from technology adoption, access to credit, and extension services are the factor significantly influnce on adoption in modern agricultural technology. Tolesa et al. (2014) conducted a research on row planting wheat crop production technology in in highland and lowland wheat producing agro-ecologies of Ethiopia. By applying logit model as a total over 248 farm households they found that row planting of wheat crop production technology enhances wheat yield of farmers in the selected highland agro-ecology; and decreases wheat yield in the lowland agro-ecology. Their studies found that improved seed, agricultural extension services, education, and livestock size are factors that significantly influence adoption of row planting wheat crop production technology.

Debela (2011) made a research entitled of on farm management and improved agricultural technology in Beressa and Umbrello Watersheds. The agricultural growth can be achieved by increasing adoption of improved agricultural technologies. Variable such as age, education level and access to credit affects significantly. (Debelo, 2015) study on Adoption of new agricultural technology in Oromia Regional State, Ethiopia using logit model as a total over 355 farmers who found that, distance from market center, age, oxen, family labor and agricultural trainings were found to affect adoption negatively and significantly while education level, livestock holding, farmer's ability, extension contact and crops net income of the households were found to affect adoption positively and significantly. Ibrahim, (2013) identify the research on adoption agricultural technology in Uganda panel data using probit model; who found that low education level, small land holding, improved seed and fertilizer technology are affects significantly.

Lastly, these reviewed literatures helped for this study to design the potential socio - economic and demographic factors related to the good quality consideration that support to explain the impact of row planting wheat crop production technology adoption on farmer wheat production. Despite the significance of wheat crop in the livelihood of many farm households and income crop in the study area, it is only most recently that few studies have been done on wheat crop. However, most of these studies focused on were limited to specific area, limited systematic adoption process and inadequate information of adoption row planting of wheat crop production technology. Hence, this study was conducted to assess the determinants of row planting of wheat crop production technology in Duna Woreda in Hadiya Zone, Ethiopia.

\section{Research Methodology}

The study was conducted in South National Regional State (ANRS), Hadiya Zone, Duna Woreda, Ethiopia. Duna Woreda is geographically located between $7^{0} 37^{\prime} 19^{\prime \prime} \mathrm{N}$ latitude and $37^{\circ} 37^{\prime} 14^{\prime \prime} \mathrm{E}$ longitudes. In this study, both primary and secondary data sources were employed. Deep discussion with farmers and agricultural sector extension staff was done to gather information. Key informants were also employed as data source from different actors. A multi stage sampling procedure was applied to select the sample kebeles and sample households. The study was applied both non-probability and probability sampling techniques to select the sample from a given population. In the first stage: Out of the total of 11 Woredas of Hadiya Zone, Duna Woreda were purposively selected, because of its high potential for wheat production, and introduction and application of row planting level of wheat crop production. In the second stage, take into account the resource available, four kebeles were selected from 23 wheat producing kebeles based on their agro ecological zone. In the third stage after lists of farmers were obtained from the district Agricultural and rural development office, farmers who were cultivating wheat in four kebeles, both 80 adopters and 107 non - adopters sample household were taken as respondent using probability proportionate selecting procedures. Respondents from both adopter and non - adopter household were selected using simple random sampling method based on their proportion. The survey was carried out in the months of May and June 2017.

In this study, descriptive statistics were mainly applied. Binary logistic regression was incorporated to analyze relationships between a dichotomous dependent variable and explanatory variables. The logistic regression was fitted employing method of wheat crop production row planting technology adoption as dependent variable and the listed demographic and socioeconomic variables as independent variables which is assumed to determine adoption of wheat crop production row planting technology. The variable is binary, taking values of one if the farmer adopts and zero otherwise. However, the explanatory variables are categorical, continuous and dummy. 
The justification for using logit is its simplicity of calculation and that its probability lies between 0 and 1 . Moreover, its probability approaches 0 at a slower rate as the value of independent variable gets smaller and smaller, and the probability approaches 1 at a slower and slower rate as the value of the independent variable gets larger and larger (Gujarati, 2003).

The function form of model or logit model is specified as follows:

$\mathrm{P}=\mathrm{E}(\mathrm{Y}=1 / \mathrm{Xi})=\frac{1}{1+\mathrm{e}^{-(\beta \mathrm{o}+\beta \mathrm{iXi})}}$.

This will be writing as follows, $z_{i}$ is equal to $\beta_{0}+\beta_{i} X_{i}$

$\mathrm{P}_{\mathrm{i}}=\frac{1}{1+\mathrm{e}^{-\mathrm{zi}}}$

$1-\mathrm{P}_{\mathrm{i}}=\frac{1}{1+\mathrm{e}^{\mathrm{zi}}}$.

The probability that a given household is row planter of wheat is expressed in equation 2 , while the probability for a non-row planter of wheat is expressed in equation 3.

Therefore, we can write as

$\frac{\mathrm{P}_{\mathrm{i}}}{1-\mathrm{P}_{\mathrm{i}}}=\frac{1 / 1+\mathrm{e}^{-\mathrm{zi}}}{1 / 1+\mathrm{e}^{\mathrm{zi}}}=\frac{1+\mathrm{e}^{\mathrm{zi}}}{1+\mathrm{e}^{-\mathrm{zi}}}=\mathrm{e}^{\mathrm{zi}}$

The ratio of the probability that household is row planter to the probability of that it is a non-row planter of wheat. $L_{i}=\ln \frac{P_{i}}{\left(1-P_{i}\right)}=z_{i}=\beta_{o}+\beta_{1} X_{1}+\beta_{2} X_{2}+\ldots \ldots \ldots+\beta_{n} X_{n}$

Where $\mathrm{L}$ is the $\log$ of the odds ratio and it is called the logit.

The above equation with disturbance term can be written as:

Where $\mathrm{z}_{\mathrm{i}}=$ function of explanatory variables $(\mathrm{X})$.

$$
\mathrm{z}_{\mathrm{i}}=\beta_{0}+\sum_{\mathrm{i}=1}^{\mathrm{n}}\left(\beta_{\mathrm{i}} \mathrm{X}_{\mathrm{i}}\right)+\mathrm{U}_{\mathrm{i}}
$$

$\beta_{0}=$ an intercept,

$\beta_{1}, \beta_{2}, \beta_{3} \ldots \ldots \beta_{n}$ are the slopes of the equation in the model

$\mathrm{L}_{\mathrm{i}}=\log$ of the odds ratio $=\mathrm{z}_{\mathrm{i}}$

$\mathrm{X}_{\mathrm{i}}=$ vector of a relevant characteristic or independent variables.

$\mathrm{U}_{\mathrm{i}}=$ disturbance term

\section{Results and Discussion}

\subsection{Respondents Background}

The number of sample farmers who practiced planting wheat in a row was $42.78 \%$ while those who used the conventional planting method comprise $57.22 \%$ of sample farmers from the total randomly selected 187 sample farmers.

Table 1: Sample farm households by adoption status (wheat planting method)

\begin{tabular}{lcc}
\hline \hline Planting method & Frequency & Percent \\
\hline Broadcast & 107 & 57.22 \\
In Row & 80 & 42.78 \\
Total & 187 & 100 \\
\hline \hline
\end{tabular}

Source: Computed from own survey data (2017)

The very majority of the respondents were headed by males $70.05 \%$ and the remaining about $29.95 \%$ of the sample households were headed by females. According to comparison by participation in row planting, out of the $100 \%$ participant's households $72.50 \%$ is headed by male participants and the corresponding figure for nonparticipants is about $68.22 \%$. Comparison by participation in row planting, out of the $100 \%$ participant's households $27.5 \%$ is headed by female participants and the corresponding figure for non-participants is about $31.78 \%$.

As regard to the age of household heads, average age of the sample household head was found to be 56.80 years where the minimum is 28 and the maximum is 81 . The average sample household age of adopters of row planting is 52.98 and the corresponding figure for non-adopters of row planting is 59.64. From the statistical analysis performed, it is found out that the mean age difference between adopters and non-adopters of row planting is 6.66. According to education level of the household heads majority sample household heads are literate $90.37 \%$, while $9.63 \%$ of sample household heads are illiterates. About $90.37 \%$ of the sample respondents were literates; this figure is greater than the national figure for adult literacy $36 \%$ showing that the area is better off in terms of education. As regard to the family size of sample household heads family size ranges between 3 and 9 . Average family size is 5.42 people per household heads. Average family size of household heads between adopters and non-adopters of row planting wheat technology were 6.00 and 5.00, and difference between adopters and nonadopters of row planting of wheat technology is 1.00 . As regard to the landholding of the sample household heads 
varies from 1.25 ha to 3 ha with an average figure of 2.39 hectares. The average livestock holding in Tropical Livestock Unit for the sample households (including cattle, horse, donkey, mule, sheep and goats, and chicken) was 10.66TLU with the minimum and the maximum holdings of 2.9 TLU and 17.2 TLU respectively. Average livestock holding in Tropical Livestock Unit for adopters and non - adopters were 11.87 TLU and 9.77 TLU respectively.

Table 2: Age, Family size, Land and Livestock Ownership

\begin{tabular}{llll}
\hline \hline & Max & Min & Average \\
\hline AGEHH & 81 & 29 & 56.80 \\
FSIZE & 9 & 3 & 5.42 \\
CLSIZE & 3 & 1.25 & 2.39 \\
TLU & 17.2 & 2.9 & 10.66
\end{tabular}

Source: Computed from own survey data (2017)

About $50.27 \%$ sample household heads have to get credit while $49.73 \%$ did not want to take credit. Majority of the adopter household heads $65.00 \%$ and non-adopters $39.25 \%$ had access to institutional credit. About $63.10 \%$ of the sample household heads get extension service and $36.90 \%$ sample households do not get extension service. About $82.50 \%$ of the adopter and $48.60 \%$ of non-adopter row planting wheat technology get extension service while $17.50 \%$ of the adopters and $51.40 \%$ non-adopters reply they do not get extension service. About $70.00 \%$ farm sample household heads had farm labor while 30.00\% did not have farm labor. As regard to Availability of farm labor in farm activity about $75.00 \%$ of adopter and $66.36 \%$ of non-adopter row planting wheat technology had farm labor while about $25.00 \%$ of adopter and $33.64 \%$ of non-adopter row planting wheat technology farmer express they do not have availability of farm labor.

\subsection{Main factors affecting adoption of row planting of wheat crop}

In this subsection, we treat results concerning adoption of row planting wheat technology at the household level as well as the socio-economic, demographic and other factors that affect the adoption of row planting wheat technology behavior of household heads. This study applied logistic regression model to estimate and to figure out factors having a certain sort of relationship to the row planting wheat technology. The output of the logistic regression model showed that seven variables determine the probability of participating in row planting wheat technology. These are the age of household head, the level of education of the household head, family size of the household head, cultivated land size of a household head, Tropical Livestock Unit (TLU), use of credit service and access to extension services.

Age of the sample household head: this variable affects adoption of row planting wheat technology negatively and significant at $1 \%$ level of significant $(\mathrm{P}=0.003)$ between adopters and non-adopters of row planting wheat technology (table 3$)$. The odds ratio (0.95) shows that odds ratio in favor of adopting row planting of wheat technology decreases by a factor of 0.95 , as the age of the small farm household head increases by 1 year (table 3).

The education level of household head: this variable is a positive relationship with row planting technology and significant at $5 \%$ of probability level $(\mathrm{P}=0.011)$ between adopters and non-adopters of row planting wheat technology (table 3). The odds ratio is (2.00) implies that as the year of schooling of household heads increased by 1 grade, household head who educated is about two times more likely to participate in row planting wheat technology as compared to household heads who are illiterate. Education helped farm household to develop perception on adoption of row planting wheat technology and production of wheat crop through time which contributes for the adopters of wheat production of row planting technology.

Family size of household head: his variable affects adoption of row planting wheat technology positively and significant at $5 \%$ of significance level $(p=0.035)$ between adopters and non-adopters of row planting wheat technology (table 3). The marginal effect (0.076) also reveals keeping all other independent variables constant, a $1 \%$ increases in family size increases household probability of adopting row planting wheat technology by $7.6 \%$. This suggests that large family size is the important variable in affecting decisions of households to participate in row planting wheat technology.

Cultivated land size of household head: this variable affects adoption of row planting wheat technology positively and significant at $10 \%$ level of significant $(\mathrm{P}=0.071)$ between adopters and non-adopters of row planting wheat technology (table 3 ). The marginal effect (0.23) implies that farmers, who have more farm size, are most likely to participate in row planting wheat crop technology, keeping the effects of other variables constant. That means households' farm size increases, the probability of participating in row planting wheat crop technology increases, ceteris paribus. As the cultivated land size increases, the household becomes able to increase row cropped area on the cultivated land.

Tropical Livestock unit (TLU): this variable is a variable positively correlated with adoption of row planting 
wheat crop technology and significant at $10 \%$ level of significant $(\mathrm{P}=0.051)$ between adopters and non-adopters of row planting wheat technology (table 3$)$. The marginal effect $(0.033)$ for tropical livestock unit implies that, other things kept constant, as the number of livestock increase by 1 TLU, the probability of household being row planter of wheat crop increase by $3.3 \%$. That means especially having many oxen make them possible to participate in row planting technology of the wheat crop.

Use of credit service of household head: this variable is a positive relationship with row planting wheat crop technology and significant at $5 \%$ level of significant $(\mathrm{P}=0.024)$ between adopters and non-adopters of row planting wheat technology (table 3). The odds ratio is (2.51) implies that the result is expected since use of credit service is major source of income for agricultural input expenditure in the rural area, hence a household heads who got credit is about two times more likely participate in row planting wheat crop technology as compared to household head who did not get credit.

Access to extension services of household head: it is positively related with adoption row planting wheat technology. This variable is significant at $1 \%$ level of significant $(\mathrm{p}=0.006)$ between adopters and non-adopters of row planting wheat technology (table 3 ). The odds ratio (2.85) this is that household heads who are involved in extension services are about three times more likely to participate in row planting wheat crop technology as compared to household head who are not involved in extension services. The data results showed that adopter household head have more contact with extension agents than non-adopter household head.

Table 3: Estimation result of row planting wheat technology adoption binary logit model $(\mathrm{n}=187)$

\begin{tabular}{|c|c|c|c|c|c|}
\hline Variable & $\begin{array}{l}\text { Robust } \\
\text { Coefficient }\end{array}$ & $\begin{array}{l}\text { Odds } \\
\text { Ratio }\end{array}$ & S.E & $\mathrm{P}>|\mathrm{Z}|$ & Marginal effect \\
\hline$\overline{\mathrm{AGEHH}}$ & $-.0467232 * *$ & .9543515 & .0156098 & 0.003 & -.0111192 \\
\hline SEHH & .116301 & 1.123334 & .4559993 & 0.799 & .027526 \\
\hline FSIZE & $319241 * *$ & 1.376083 & .1512633 & 0.035 & .0759728 \\
\hline EDU & $.693629 * *$ & 2.000964 & .2711641 & 0.011 & .1650696 \\
\hline CLSIZE & $.9678345^{*}$ & 2.632238 & .5360575 & 0.071 & .2303249 \\
\hline TLU & $.1399694 *$ & 1.150239 & .0716798 & 0.051 & .0333099 \\
\hline CRUHH & $.9171961 * *$ & 2.502264 & .405024 & 0.024 & .2149421 \\
\hline RAI & .5425498 & 1.720388 & .3887685 & 0.163 & .1279105 \\
\hline AFL & .1734129 & 1.189357 & .454173 & 0.703 & .0409221 \\
\hline EXTEN & $1.046396 * * *$ & 2.847372 & .384173 & 0.006 & .236481 \\
\hline Cons & -6.696468 & .0012353 & 1.859443 & 0.000 & \\
\hline \multicolumn{2}{|c|}{ LR chi2 (10) } & & Pseudo R2 & & 0.334 \\
\hline \multicolumn{2}{|c|}{ Prob $>$ chi 2} & & Log likeli & & -85.038 \\
\hline
\end{tabular}

\section{Conclusion and Recommendation}

The objective of this study was to evaluate the factor that influences adoption row planting wheat crop technology. Binary logit and cross-sectional survey data were employed to attain the objective of the study. The study applied cross sectional household level data collected in 2016/2017 cropping season from 187 samples farming household head. The main factors influencing adoption of row planting wheat crop technology are the age of household head, education level household head, family size, size of cultivated land, holding of livestock, use of credit services and extension services. Therefore, it is used to scaling up the best wheat crop row planting technology and practices of the adopters to other farmers can be considered as one option while introducing new agricultural practices and technologies is another option.

The most crucial problem in practicing adoption of row planting wheat crop production technology is its knowledge requirement, associated costs, and skill application and management in successfully managing, fertilizer, and pesticide application test and preference of consumer demand. So a government has to create awareness about benefits of adoption adopting row planting of wheat crop production technology. Therefore, changing the attitudes of farmers is an important factor in adopting row planting of wheat crop production technology. Increasing the number of cooperatives organization in the rural area in which the farmers will be able to get credit are bamsis in enhancing the adopting of row planting wheat crop production technology. Thus, the credit facility should target poor farmers especially those who were not adopting the row planting of wheat crop production technology due to lack of operating capital. This may encourage the farmers to do commercial farming practice in which they can build their asset to implement the adoption of row planting of wheat crop production technology on their farms. The agricultural research and extension is a crucial factor in adopting row planting of wheat crop production technology. In case of extension, a significant proportion of farmers had no formal education; the extension program should be targeted to the less educated farmers for its effective delivery through special training, seminars, field demonstrations, and technical support should be facilitated to enhance the adopting 
rate of row planting of wheat crop production technology. The improved access to diversified and qualified agricultural extension service still remains critically important for the technology.

\section{REFERENCE}

[1] Abraham B, Araya H, Berhe T, Edwards S, Gujja B, Khadka R, Sen D, Koma Y, Sharif A, and Styger E. (2014). The system of crop intensification: Reports from the field on Improving agricultural production, food security, and resilience to climate change for multiple crops. Addis Ababa, Ethiopia.

[2] Alemitu, m. (2011). Factors Affecting Adoption of Improved Haricot Bean Varieties and Associated Agronomic Practice in Dale Woreda, SNNPRS. MA Thesis a Hawassa University, Hawassa. 40p. ,

[3] FAO. (2009). How to feed the world in 2050. (www.fao.org/fileadmin/templates/wsfs/docs/ expert paper /Howto feed the World in 2050.

[4] FAO. (2014). Voluntary Guidelines on Flag State Performance. In: FAO Fisheries and Aquaculture Department. Rome. [Cited 8 May 2016].

[5] Feder, L., R.E.,Just and O., Zilberman, (1985). Adoption of Agricultural Innovation in Developing Countries: A survey. Economic Development and Cultural change 32(2):255.

[6] Gujarati, D. ( 2003). Basic Econometrics. 4th Edition. McGraw-Hill, New York. pp. 563-636.

[7] Lulit M, Ermias E, and Zelalem H, (2012). Public investment in irrigation and training for agriculture-Led development: a CGE approach for Ethiopia. Addis Ababa, Ethiopia.

[8] Mamudu AA, Emelia G, and Samuel KD. (2012). Adoption of modern agricultural production technologies by farm households in Ghana: What factors influence their decisions? J. Biol. Agric. Healthcare 2(3).

[9] MEDAC. (1999). Survey of the Ethiopian Economy Review of post-Reform Development (1992/93-1997). Addis Ababa, Ethiopia.

[10] Rashid, S. (2010). Staple food prices in Ethiopia. Maputo, Mozambique.

[11] Sarah, M. (2014). IFPRI evaluates a new wheat package rollout in Ethiopia.

[12] Tolesa A, Bezabih E, Jema H, and Belaineh L. (2014). The impact of Wheat Row Planting on Yield of Smallholders in Selected Highland and Lowland Areas of Ethiopia. International Journal of Agriculture and Forestry 2014, 4(5):, 386-393.

[13] Tolesa Alemu, Bezabih Emana, Jema Haji, and Belaineh Legesse. (2014). The impact of Wheat Row Planting on Yield of Smallholders in Arsi Zone of Ethiopia. International Journal of Economics and Empirical Research, 510-517.

[14] Tsegaye, M.and Bekele, H. (2012). Impacts of Adoption of Improved Wheat Technologies on Household'se Food Consumption in Southeastern Ethiopia.Selected Poster prepared for Presentation at the International Association of Agricultural Economists (IAAE) Triennial Conference, Foz d Iguaçu, 18-24.

[15] World Bank (2014). Ethiopia poverty Assessment. Document of the WB for official use only. 